\title{
EFFECT OF CRYOPRESERVATION AND HISTOCOMPATIBILITY ON TYPE I PROCOLLAGEN GENE EXPRESSION IN AORTIC VALVE GRAFTS
}

Ying C. Song, MB, PhD

Lena Y. Yao, PhD

James M. Kneebone, MS

Flavian M. Lupinetti, MD
Background: Allograft valves are excellent substitutes for diseased or absent valves but undergo primary tissue degeneration. Fibroblast viability may determine resistance to valve deterioration. This study evaluated gene expression for procollagen by valve grafts and studied the effects of cryopreservation and histocompatibility on this property. Methods and results: Fresh and cryopreserved rat aortic valves were implanted heterotopically into syngeneic or allogeneic recipients. Nonviable, cryothermally injured valves were used as negative controls. The grafts and native aortic roots were excised 3 days after implantation. Northern hybridization with a human procollagen $\alpha_{1}(\mathrm{I})$ complementary DNA probe was used to assess the expression of type I procollagen mRNA. The content of procollagen mRNA relative to $18 S$ ribosomal RNA was evaluated by means of scanning densitometry. In situ hybridization was used to locate the areas of procollagen mRNA expression in the grafts. Both fresh and cryopreserved grafts exhibited greater expression than the native valve. This increase in expression was observed in both syngeneic and allogeneic grafts, but not in the negative control group. In situ hybridization showed a strong signal for procollagen in the aortic wall and a weak signal in the leaflet and myocardium in the viable grafts and in native tissues. Conclusions: Regardless of preservation or allogenicity, fibroblast viability in aortic valve grafts persists after implantation. Increased gene expression for procollagen suggests a capacity for repair and regeneration. (J Thorac Cardiovasc Surg 1997;114:421-7)
A though aortic valve replacement with human allograft valves achieves excellent early results, eventual failure of these tissues is common. ${ }^{1-4}$ The precise cellular events initiating allograft valve failure are unclear. Heretofore, studies of the causes of allograft valve failure have not succeeded in conclusively determining the mechanisms of degeneration.

From the Department of Surgery, Division of Cardiac Surgery, and the Department of Urology, Children's Hospital and Medical Center and the University of Washington, Seattle, Wash.

Supported by grants 94-WA-532 and 95-WA-507R from the Washington Affiliate of the American Heart Association and by a grant from the Research Endowment of Children's Hospital and Medical Center.

Received for publication Dec. 26, 1996; accepted for publication April 28, 1997.

Address for reprints: Flavian M. Lupinetti, MD, Division of Cardiac Surgery, Children's Hospital and Medical Center, 4800 Sand Point Way N.E., Seattle, WA 98105.

Copyright (C) 1997 by Mosby-Year Book, Inc.

$0022-5223 / 97 \$ 5.00+0 \quad \mathbf{1 2 / 1 / 8 2 9 1 8}$
Ongoing controversies concern models of failure, demonstration of cellular viability, durability of the extracellular matrix, and the contribution of the immune response. ${ }^{5,6}$ Regardless of the specific cellular events associated with valve failure, significant morbidity and mortality and a need for reoperations are the results. Many investigators have speculated that the cell viability in aortic valve allografts is crucial in determining the long-term fate of the valve. $^{1,7-9}$ If this is true, then the specific cell population of greatest importance is likely to be the fibroblasts. These cells are by far the most abundant in aortic valves and are responsible for protein synthesis and structural integrity.

Although previous examinations of aortic valve grafts have successfully demonstrated the presence or absence of endothelial cell viability in vivo, ${ }^{10}$ viability of the fibroblast population has not been demonstrated except in in vitro models. Unlike the endothelial cell, whose relatively rapid rate of replication allows convenient methods of assessing viability, the fibroblast replicates slowly and less pre- 
dictably. Consequently, the evaluation of in vivo fibroblast viability requires a method of study that is based on normal metabolic activities of the cell. Such a technique may be useful not only in demonstrating that the fibroblasts are alive, but also in showing that they are functioning in a way that may contribute to the structural integrity of the tissue. This investigation was undertaken to assess procollagen gene expression as a marker for fibroblast viability in aortic valve grafts in a rat model and to use this technique to evaluate the effects of cryopreservation and histocompatibility on viability.

\section{Materials and methods}

Aortic valve implantation. Inbred male rats underwent heterotopic transplantation of aortic valve allografts as described by Yankah and associates. ${ }^{11}$ Under general anesthesia with intraperitoneal sodium pentobarbital (60 $\mathrm{mg} / \mathrm{kg}$ body weight), donor rats weighing 100 to $150 \mathrm{gm}$ underwent a midline sternotomy, exposing the heart and ascending aorta. The aortic root was excised with a $1 \mathrm{~mm}$ cuff of ventricular muscle and a $5 \mathrm{~mm}$ portion of distal artery to permit construction of anastomoses. Some valves were transplanted immediately. All valves not used immediately were subjected to antibiotic sterilization and controlled-rate cryopreservation by CryoLife, Inc. (Marietta, Ga.). At the time of implantation, recipient rats weighing 200 to $250 \mathrm{gm}$ underwent sterile laparotomy and dissection of the abdominal aorta. The recipient aorta was occluded proximally and distally with vascular clamps and divided. An end-to-end anastomosis of the distal end of the valve graft to the distal end of the native aorta was performed with $8-0$ polypropylene suture. Then a similar end-to-end anastomosis between the proximal end of the graft and the proximal end of the native aorta was constructed. No leaflet was intentionally included in the suture line; thus it is possible that competence of the valve was maintained. Whether valve opening and closing actually occurs in this model is unknown, however. The coronary ostia were sutured closed. The aortic clamps were removed, the abdomen was closed, and the animals were allowed to recover. All implantation procedures were performed with a stereoscopic zoom microscope with a usual magnification of $9 \times$. The grafts were left in place for 3 days. Then the rats were again subjected to general anesthesia, the grafts and the native aortic roots were excised, and the animals were killed.

All grafts used in this study were obtained from Lewis rats and were implanted into Lewis rats (syngeneic) or Brown-Norway rats (strongly allogeneic). Thus four experimental groups of potentially viable grafts were studied: fresh syngeneic, fresh allogeneic, cryopreserved syngeneic, and cryopreserved allogeneic. To provide control valves composed of nonviable tissue, we implanted additional valves after subjecting them to cryothermal injury. Each such valve was immersed in liquid nitrogen for 20 seconds without cryoprotectant and completely thawed at room temperature. The freezing-thawing cycle was performed three times for each valve. All animals received humane care in compliance with the "Guide for the Care and Use of Laboratory Animals" prepared by the Institute of Laboratory Animal Resources and published by the National Institutes of Health (NIH Publication No. 86-23, revised 1985)

Northern blot, in situ hybridization, and histology. The retrieved tissues were snap frozen, pulverized, and homogenized. Total RNA was isolated by means of the guanidinium isothiocyanate extraction method. ${ }^{12}$ Quantities of RNA were determined by spectrophotometric absorbance at $260 \mathrm{~nm}$. For Northern blot analysis, $5 \mu \mathrm{g}$ of RNA was denatured and electrophoresed in a $1 \%$ formaldehyde agarose gel, transferred to a nitrocellulose transfer membrane (Micron Separations Inc., Westboro, Mass.), and cross-linked to the membrane with short-wave ultraviolet light. The prehybridizing and hybridizing solutions contained $50 \%$ formamide, $1 \times$ Denhardt's solution, $6 \times$ saline-sodium phosphate-ethylenediaminetetraacetic acid buffer (SSPE buffer), and 1\% sodium dodecyl sulfate (SDS). Complementary DNA (cDNA) probes were labeled with $\left.{ }^{32} \mathrm{P}\right]$ deoxycytidine triphosphate by random primer extension (PRIME-IT II, Stratagene, La Jolla, Calif.) and added to the hybridizing solution to a specific activity of $1 \times 10^{6} \mathrm{cpm} / \mathrm{ml}$. Hybridization was performed at $42^{\circ} \mathrm{C}$ for 14 to 18 hours. The blots were then washed several times with a final wash in $0.1 \times$ standard sodium citrate (SSC) solution and $0.1 \%$ SDS at $37^{\circ} \mathrm{C}$. The blots were exposed on Kodak X-omat film (Eastman Kodak Co., Rochester, N.Y.) at $-70^{\circ} \mathrm{C}$. The relative content of procollagen mRNA was evaluated by scanning densitometry with a PhosphorImager model $400 \mathrm{~S}$ and ImageQuant quantitation software (Molecular Dynamics, Sunnyvale, Calif.). The closest upstream position of each band, respectively, was taken as the background of the image and subtracted from the total reading. RNA loading was normalized by comparison to $18 \mathrm{~S}$ ribosomal RNA. Results were expressed as the fold increase above value obtained from corresponding native aortic root controls.

For in situ hybridization detection of procollagen mRNA and routine histologic preparation, tissues were frozen in cutting medium and cut into $8 \mu \mathrm{m}$ sections. After fixation, the samples were hybridized with a ${ }^{35} \mathrm{~S}$ labeled human $\alpha_{1}(\mathrm{I})$ procollagen oligo probe, and the background was stained by hematoxylin. Other sections were stained with hematoxylin-eosin for routine histologic examination.

Molecular probes. Procollagen $\alpha_{1}$ (I) (HF677), a human cDNA, and a $1.5 \mathrm{~kb}$ human cDNA for $18 \mathrm{~S}$ ribosomal RNA were obtained from the American Type Culture Collection, Rockville, Maryland. The human $\alpha_{1}(\mathrm{I})$ procollagen gene is $18 \mathrm{~kb}$ in length, and its coding information is subdivided in 51 exons. ${ }^{13}$ The human cDNA probe used in this study is cloned from human fibroblasts. It spans from the nucleotides coding for amino acid residue 787 in the triple helical domain for 270 base pairs into the $3^{\prime}$ untranslated region. The sequences of the $\alpha_{1}(\mathrm{I})$ procollagen oligo probe, TGATTGGTGGGATGTCTTCGTCTT, is 24 base pairs long, from exon 1 and exon 2 of the human $\alpha_{1}$ (I) procollagen gene. Human probes can be used for study of rat tissues, because sequence conservation is greater than $90 \%$ among all mammalian species. ${ }^{14}$

Statistical analysis. All values are reported as group means \pm standard error of the mean. Statview 4.01 

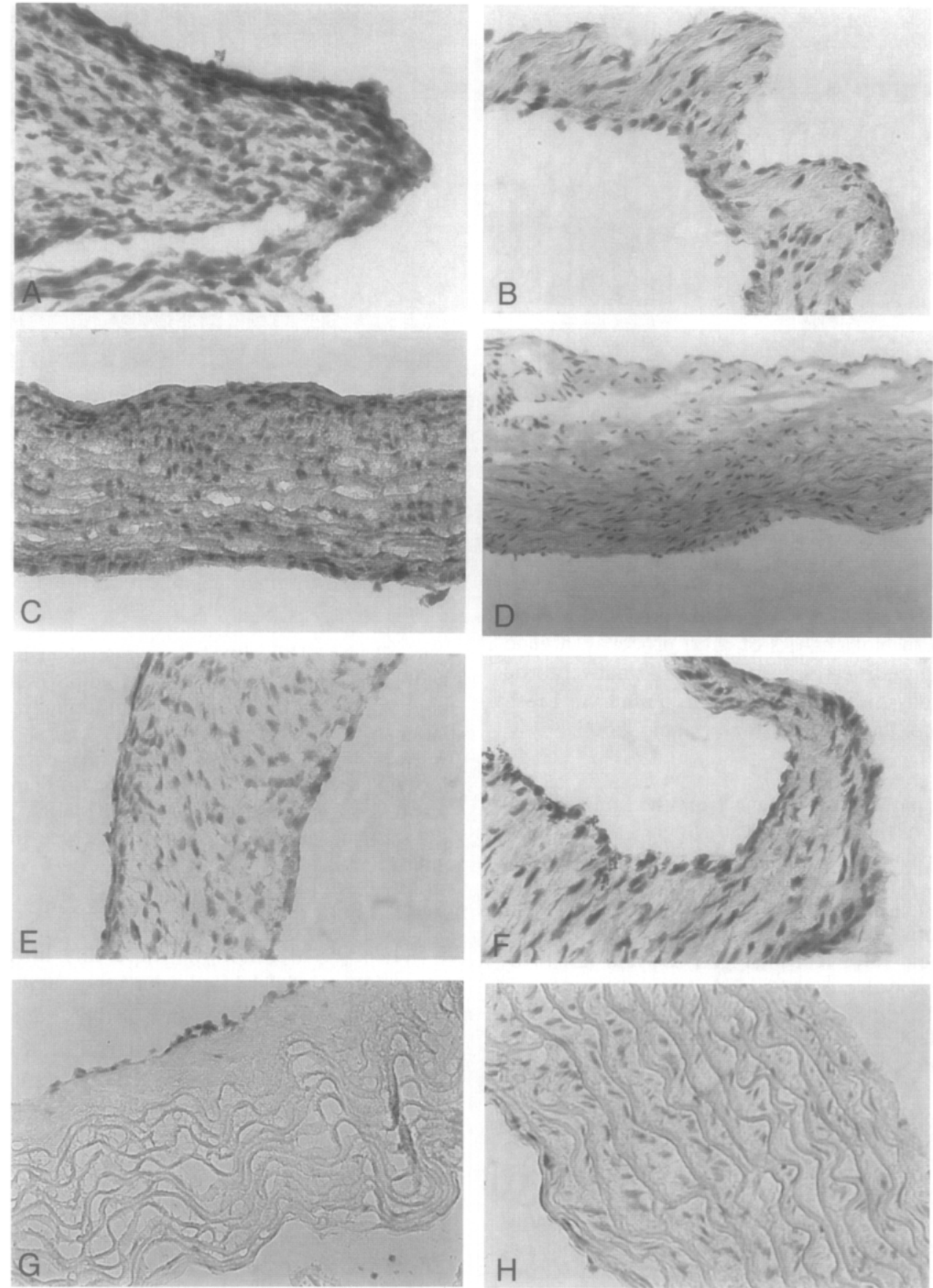

Fig. 1. Sections of aortic valve grafts and corresponding native aortic valves stained with hematoxylin and eosin. A valve leaflet from a cryopreserved allograft (A) and a native valve leaflet from the same animal (B). An aortic wall of a cryopreserved allograft $(\mathbf{C})$ and a native aortic wall from the same animal (D). A valve leaflet from a cryopreserved syngeneic graft $(\mathbf{E})$ and a native valve leaflet from the same animal (F). A valve leaflet of a cryothermally injured negative control graft (G) and a native valve leaflet from the same animal (H). (All original magnifications $\times 400$.)

(Abacus Concepts, Inc., Berkeley, Calif., 1993) was used for statistical analysis. Differences among groups were analyzed by means of analysis of variance. Post hoc comparisons between groups were then carried out with the use of Scheffe's F test. Differences were considered significant at the level $p<0.05$.

Fig. 1, $A$ to $H$ shows photomicrographs of hematoxylineosin-stained sections from aortic valve grafts and the 


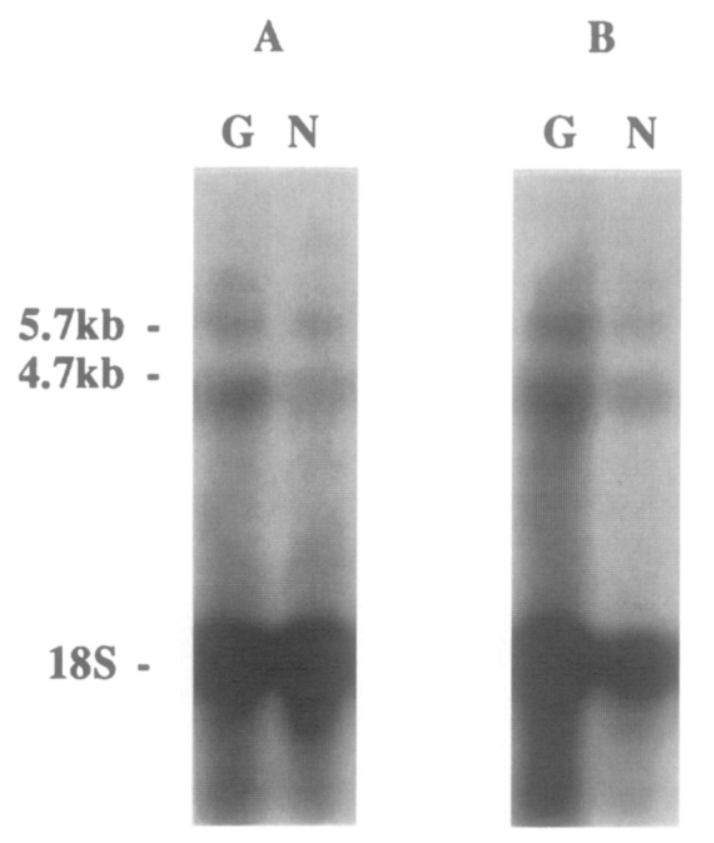

Fig. 2. Northern blot analysis of $\alpha_{1}(\mathrm{I})$ procollagen gene expression in an aortic valve graft $(G)$ and native aortic valve $(N) 3$ days after implantation. Panel A, Fresh syngeneic group. Panel B, Fresh allogeneic group.

corresponding native aortic tissues from the same animal. The cellularity of the cryopreserved allograft valve leaflet (Fig. $1, A$ ) was similar to that of the native aortic valve leaflet (Fig. 1, $B$ ). The aortic wall of the cryopreserved allograft valve (Fig. 1, C) showed a similar cell density to that of the native aorta (Fig. 1,D). Also, the cryopreserved syngeneic valve leaflet (Fig. $1, E$ ) and its corresponding native valve leaflet (Fig. 1,F) were of like cellular density. On the other hand, the cryothermally injured valve leaflet (Fig. 1, $G$ ) demonstrated a complete absence of cells, contrasting sharply with the native valve leaflet (Fig. 1, $H$ ).

As shown in Fig. 2, valve grafts exhibited gene expression of type I procollagen as exemplified by the bands located at 4.7 and $5.7 \mathrm{~kb}$. As compared with the corresponding native valve, the graft appeared to have more abundant procollagen gene expression. Table I demonstrates the densitometry-derived quantitative expression for procollagen mRNA in average arbitrary units corresponding to the volume obtained by scanning densitometry. Compared with the native aortic valve, the transcriptional activity of $\alpha_{1}(\mathrm{I})$ procollagen mRNA in each group of valve grafts except for the cryothermally injured group was approximately threefold greater. Cryopreserved grafts and fresh grafts exhibited similar degrees of up-regulation of procollagen gene expression, as did syngeneic and allogeneic grafts. Only in the cryothermally injured controls was procollagen gene expression less than that in the native aortic roots.

In situ hybridization confirmed the Northern blot findings (Figs. 3 to 5). Both in native aortic roots and in the grafted valves, there was gene expression for type I

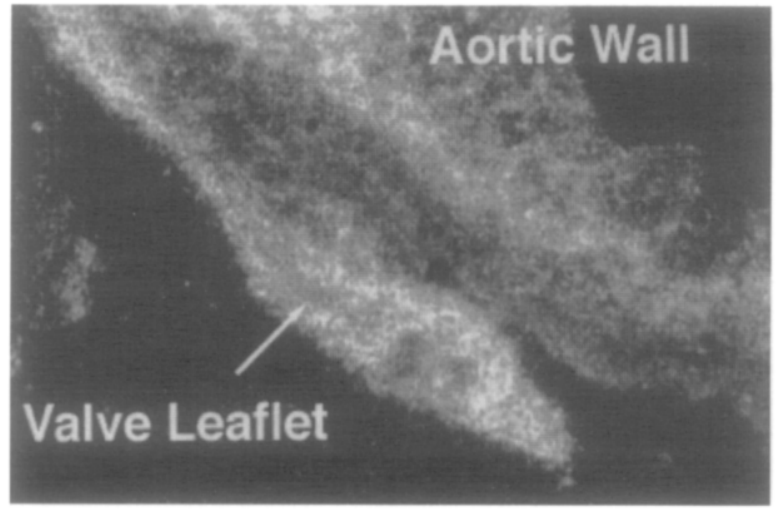

Fig. 3. Dark-field photomicrograph showing localization of $\alpha_{1}(\mathrm{I})$ procollagen $\mathrm{mRNA}$ by in situ hybridization in a fresh syngeneic graft implanted for 3 days. Silver grains reflecting the bound probe were observed predominantly in the aortic wall, particularly in the hinge region of the valve. There is a less intense signal in the free portion of the leaflet. (Original magnification $\times 400$.)

procollagen. This signal was greatest in the aortic wall, with a less intense signal in the free portion of the leaflet and the myocardium. In the cryothermally injured grafts, almost no signal was detectable except on the tissue surrounding the aortic wall. These in situ hybridization results correspond to the histologic findings, that is, gene expression is found only in tissues where cells are also present; no gene expression is observed in the acellular areas.

\section{Discussion}

These results demonstrated that fibroblast viability of both fresh and cryopreserved aortic valve grafts remains intact after 3 days of implantation. This viability persists similarly in syngeneic and strongly allogeneic grafts. The increase in gene expression for procollagen exceeding that observed in native aortic roots suggests a capacity for repair and regeneration in grafts at this early duration of implantation. This may help to explain the excellent early results of aortic valve allograft implantation that are observed clinically. It is the impression of some investigators that the long-term success of allograft valves is related to the viability of the valve fibroblasts. ${ }^{1,7-9}$ It is logical to expect the structural integrity of the valve to depend on the maintenance of the extracellular matrix, which in turn depends on functioning fibroblasts. The fibroblasts are responsible for continuous degradation and synthesis of extracellular matrix proteins and must participate at some level in repairing and remodeling of the valve tissue. Previously published studies have not investigated the gene expression for these important 


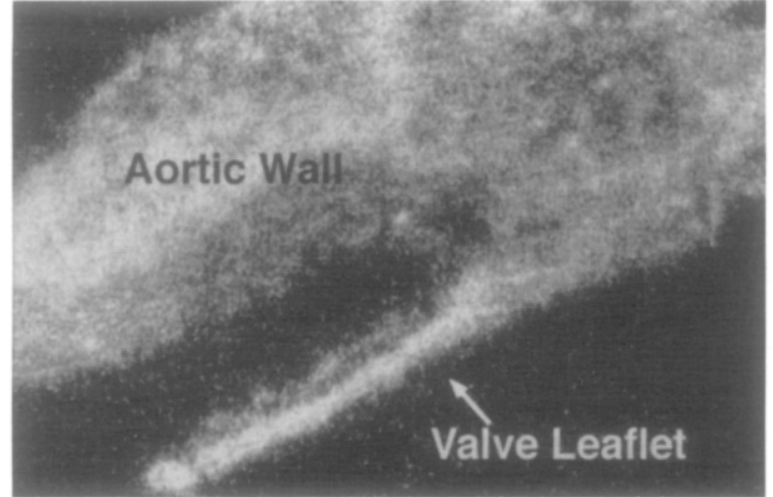

Fig. 4. Dark-field photomicrograph showing localization of $\alpha_{1}(\mathrm{I})$ procollagen mRNA by in situ hybridization in a cryopreserved allogeneic graft implanted for 3 days. Silver grains reflecting the bound probe were observed in a distribution similar to that in the fresh syngeneic graft (see Fig. 2). (Original magnification $\times 400$.)

structural proteins. The present study, therefore, is significant for demonstrating in vivo fibroblast viability as evidenced by performance of a metabolic activity that may be important in assuring continued valve function.

The aortic valve leaflet consists of a cellular component and a noncellular component. Part of the cellular component is the endothelium, forming a smooth boundary lining the leaflet. Smooth muscle is also present in the aortic wall, and a contribution from these cells must also be considered. Fibroblasts exist within the noncellular matrix, which is composed primarily of collagen, elastin, and proteoglycans. Collagen represents the largest portion of the extracellular matrix in the aortic valve, and type I collagen is the most abundant type. ${ }^{15}$ Maintenance of the normal rate of type I collagen synthesis may be important for preservation of normal tissue structure and function. If the cellular viability of fibroblasts helps to determine the capacity of the graft to resist deterioration, this may be mediated by the production of procollagen.

For a negative control, this study used a group of grafts in which the cells had been cryothermally injured by rapid freezing and thawing. These grafts, which were essentially acellular, had diminished procollagen gene expression compared with all other groups. This negative control group was important for two reasons: (1) it demonstrates that detection of increases in procollagen gene expression requires fibroblast viability and (2) it suggests that the donor cells, not the recipient tissues, are the

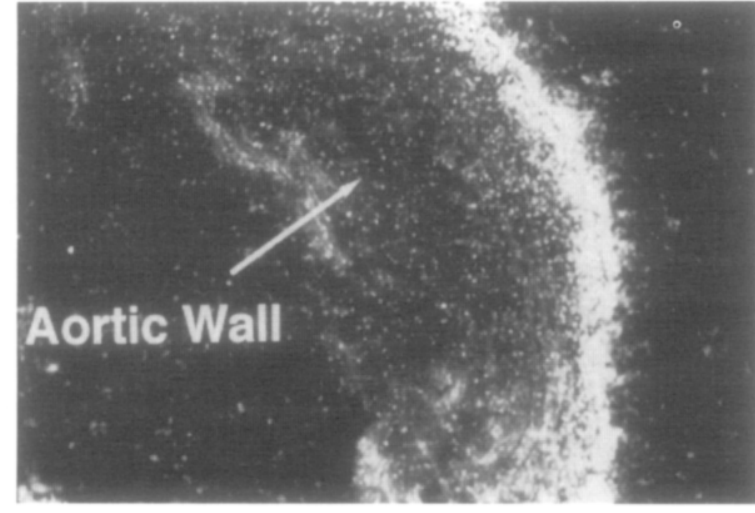

Fig. 5. Dark-field photomicrograph showing localization of $\alpha_{1}(\mathrm{I})$ procollagen mRNA by in situ hybridization in a cryothermally injured graft implanted for 3 days. Silver grains reflecting the bound probe were observed only on the adventitia of the aortic wall, indicating an absence of gene expression throughout most of the graft. (Original magnification $\times 400$.)

Table I. Transcriptional activity of type I procollagen $m R N A$ in grafts and native aortic valves

\begin{tabular}{|c|c|c|c|c|}
\hline Group & $\begin{array}{l}\text { Sample } \\
(n)\end{array}$ & $\begin{array}{l}\text { Graft! } \\
\text { native }\end{array}$ & $\begin{array}{c}\text { Transcriptional } \\
\text { activity } \\
\text { (mean } \pm \text { SEM) }\end{array}$ & $\begin{array}{c}\text { Fold } \\
\text { increase }\end{array}$ \\
\hline Fresh syngeneic & 13 & $\begin{array}{l}\text { Graft } \\
\text { Native }\end{array}$ & $\begin{array}{l}2.38 \pm 0.75 \\
0.74 \pm 0.22\end{array}$ & $3.64 \pm 0.53^{*}$ \\
\hline Fresh allogeneic & 11 & $\begin{array}{l}\text { Graft } \\
\text { Native }\end{array}$ & $\begin{array}{l}1.30 \pm 0.25 \\
0.46 \pm 0.10\end{array}$ & $3.58 \pm 0.68^{*}$ \\
\hline $\begin{array}{l}\text { Cryopreserved } \\
\text { syngeneic }\end{array}$ & 10 & Graft & $2.53 \pm 0.61$ & $3.31 \pm 0.49 \dagger$ \\
\hline \multirow{2}{*}{$\begin{array}{l}\text { Cryopreserved } \\
\text { allogeneic }\end{array}$} & 14 & $\begin{array}{l}\text { Native } \\
\text { Graft }\end{array}$ & $\begin{array}{l}0.80 \pm 0.17 \\
1.08 \pm 0.54\end{array}$ & \multirow[t]{2}{*}{$3.10 \pm 0.35 \dagger$} \\
\hline & & Native & $0.59 \pm 0.37$ & \\
\hline \multirow{2}{*}{$\begin{array}{l}\text { Cryothermally } \\
\text { injured } \\
\text { controls }\end{array}$} & 8 & Graft & $0.52 \pm 0.09$ & \multirow[t]{2}{*}{$0.64 \pm 0.03$} \\
\hline & & Native & $0.82 \pm 0.14$ & \\
\hline
\end{tabular}

${ }^{*} p<0.01$ versus cryothermally injured controls.

$\ddagger p<0.05$ versus cryothermally injured controls.

source of the gene expression. It is possible that with longer times of observation, recipient cells may repopulate the graft and serve as a source for protein synthesis. It is unlikely, however, that such recipient cell migration could occur in the short time frame used in this study.

Although one of the underlying premises of this investigation is that procollagen gene expression, procollagen protein synthesis, and collagen assembly are advantageous in maintaining graft structure 
and function, this is by no means a given. Additional investigations will be necessary to support this premise. It may eventually prove to be the case that procollagen overproduction leads to fibrosis, calcification, and graft stenosis. Because the pathologic fate of allograft valves is not consistent, the pathophysiologic events leading to the common endpoint of "allograft failure" may be markedly divergent. Whereas some allograft valve failures are characterized by attenuation of leaflets and insufficiency, others are noteworthy for fibrosis, loss of compliance, and mineralization. ${ }^{16,17}$ It is not known whether these seemingly opposite types of events can be related to a uniform cellular process.

Similarly, the lack of apparent difference in histocompatible and incompatible grafts may be an artifact of a short-term study. Immunologic influences are unlikely to become manifest within a 3-day period but may be considerably stronger over a longer time. Allograft valves are almost always used without HLA matching between donors and recipients, and even matching by $\mathrm{ABO}$ blood group antigens is done in a minority of cases. Although sensitization of valve graft recipients has been shown in both human beings ${ }^{18,19}$ and experimental animals, ${ }^{11,20-22}$ the performance of allograft valves seems unaffected by the degree of immunologic difference between donor and recipient. ${ }^{1,6,23} \mathrm{Ex}$ perimental findings support a limited link between histocompatibility and allograft valve calcification. ${ }^{21}$

The importance and role of the increase of procollagen gene expression in aortic valve grafts needs further study now that the methods of investigating the modulators of gene expression are available. Procollagen gene expression is regulated both positively and negatively by a variety of factors such as growth factors, cytokines, and other modulators of gene expression. ${ }^{24}$ In vivo studies of regulation, composition, interactions, and organization of various connective tissues are complex and difficult. For this reason, cell culture systems are frequently used for these purpose. Cells in culture, however, are not exposed to many of the modulating influences that exist in vivo. Most experiments examining the effects of exogenous agents on collagen gene expression have examined individual factors, whereas, in vivo, a given cell will always be exposed to several factors simultaneously. It seems likely that many of these factors acting in combination will have different effects from those acting separately. Most previously published studies examining the cellular viability of allograft valves use specimens obtained immediately after harvest, disinfection, or thawing, but not after subsequent implantation. ${ }^{7-9,25,26}$ Thus influences of implantation, including immunologic consequences, are not considered. Such studies may not be able to predict long-term fibroblast viability in implanted valves. Therefore determining fibroblast viability in allograft valves after implantation is valuable. Previous studies from this laboratory demonstrated that early endothelial viability was well maintained in fresh grafts, whether syngeneic or allogeneic, but completely abolished in cryopreserved grafts. ${ }^{10}$ The present study thereby illustrates a sharp divergence of the pathologic fate of these two cellular components of the valve and emphasizes the importance of analyzing the cell populations independently.

In conclusion, this experiment successfully demonstrates the use of molecular techniques to evaluate procollagen gene expression in aortic valve grafts at an early period after transplantation. These observations suggest that during this period, graft repair processes are present and perhaps accelerated compared with those of native tissues. This also suggests that fibroblast viability is maintained and that cryopreservation and histocompatibility differences do not alter the ability of these cells to respond appropriately to endogenous signals.

\section{REFERENCES}

1. O'Brien MF, Stafford EG, Gardner MAH, Pohlner PG, McGiffin DC. A comparison of aortic valve replacement with viable cryopreserved and fresh allograft valves, with a note on chromosomal studies. J Thorac Cardiovasc Surg 1987;94:81223.

2. Bodnar E, Matsuki O, Parker R, Ross DN. Viable and nonviable aortic homografts in the subcoronary position: a comparative study. Ann Thorac Surg 1989;47:799-805.

3. O'Brien MF, Stafford EG, Gardner MAH, Pohlner PG, Tesar PJ, Cochrane AD, et al. Allograft aortic valve replacement: long-term follow-up. Ann Thorac Surg 1995;60:S65-70.

4. Yacoub MH, Rami NR, Sundt TM, Lund O, Boyland E, Radley-Smith R, et al. Fourteen-year experience with homovital homografts for aortic valve replacement. J Thorac Cardiovasc Surg 1995;110:186-93.

5. Wolfinbarger L $\mathbf{J r}$, Hopkins RA. Biology of heart valve cryopreservation. In: Hopkins RA, editor. Cardiac reconstructions with allograft valves. New York: Springer-Verlag; 1989. p. 21-36.

6. Mitchell RN, Jonas RA, Schoen FJ. Structure-function correlations in cryopreserved allograft cardiac valves. Ann Thorac Surg 1995;60:S108-13.

7. Nakayama S, Ban T, Okamoto Y. Fetal bovine serum is not necessary for the cryopreservation of aortic valve tissues. J Thorac Cardiovasc Surg 1994;108:583-6.

8. Crescenzo DG, Hilbert SL, Messier RH Jr, Domkowski PW, Barrick MK, Lange PL, et al. Human cryopreserved ho- 
mografts: electron microscopic analysis of cellular injury. Ann Thorac Surg 1993;55:25-31.

9. Abd-Elfattah AS, Messier RH Jr, Domkowski PW, Jones JL, Aly HM., Crescenzo DG, et al. Inhibition of adenosine deaminase and nucleoside transport: utility in a model of homograft cardiac valve preimplantation processing. $J$ Thorac Cardiovasc Surg 1993;105:1095-105.

10. Lupinetti FM, Tsai TT, Kneebone JM. Endothelial cell viability in an in vivo model of aortic allografts. Ann Thorac Surg 1993;56:237-41.

11. Yankah AC, Wottge HU, Muller-Rucholtz W. Prognostic importance of viability and a study of a second set allograft valve: an experimental study. J Card Surg 1988;3:263-70.

12. Chomczynski P, Sacchi N. Single-step method of RNA isolation by acid guanidium thiocyanate-phenol-chloroform extraction. Anal Biochem 1987;162:156-9.

13. Chu M-L, de Wet W, Bernard M, Ramirez F. Fine structural analysis of the human pro- $\alpha_{1}$ (I) collagen gene: promoter structure, AluI repeats, and polymorphic transcripts. J Biol Chem 1985;260:2315-20.

14. Bernard MP, Chu M-L, Myers JC, Ramirez F, Eikenberry EF, Prockop DJ. Nucleotide sequences of complementary deoxyribonucleic acids for the pro $\alpha_{1}$ chain of human type I procollagen: statistical evaluation of structures that are conserved during evolution. Biochemistry 1983;22:5513-23.

15. Garcia-Martinez V, Sanchez-Quintana D, Hurle JM. Histogenesis of the semilunar valves: an immunohistochemical analysis of tenascin and type-I collagen distribution in developing chick heart valves. Cell Tissue Res 1990;259:299-304.

16. Ross DN, Gonzalez-Lavin L. Homograft aortic valve replacement. In: Ionescu MI, Ross DN, Wooler GH, editors. Biologic tissue in heart valve replacement. London: Butterworths; 1972. p. 287-312.
17. Clarke DR, Campbell DN, Hayward AR, Bishop DA. Degeneration of aortic valve allografts in young recipients. J Thorac Cardiovasc Surg 1993;105:934-42.

18. Smith JD, Ogino H, Hunt D, Laylor RM, Rose ML, Yacoub $\mathrm{MH}$. Humoral immune response to human aortic valve homografts. Ann Thorac Surg 1995;60:S127-30.

19. Fischlein T, Schutz A, Haushofer M, Frey R, Uhlig A, Detter $\mathrm{C}$, et al. Immunologic reaction and viability of cryopreserved homografts. Ann Thorac Surg 1995;60:S122-6.

20. Lupinetti FM, Christy JP, King DM, E1 Khatib H, Thompson SA. Immunogenicity, antigenicity, and endothelial viability of aortic valves preserved at $4^{\circ} \mathrm{C}$ in a nutrient medium. J Card Surg 1991;6:454-61.

21. Lupinetti FM, Cobb S, Kioschos HC, Thompson SA, Walters $\mathrm{KS}$, Moore KC. Effect of immunologic differences on rat aortic valve allograft calcification. J Card Surg 1992;7:65-70.

22. Zhao X, Green M, Frazer IH, Hogan P, O'Brien MF. Donor-specific immune response after aortic valve allografting in the rat. Ann Thorac Surg 1994;57:1158-63.

23. Balch CM, Karp RB. Blood group compatibility and aortic valve allotransplantation in man. J Thorac Cardiovasc Surg 1975;70:256-9.

24. Bornstein $P$, Sage $H$. Regulation of collagen gene expression. Prog Nucleic Acid Res Mol Biol 1989;37:67-106.

25. van der Kamp AWM, Visser WJ, van Dongen JM, Nauta J, Galjaard H. Preservation of aortic heart valves with maintenance of cell viability. J Surg Res 1981;30:47-56.

26. Hu J, Gilmer L, Hopkins R, Wolfinbarger L Jr. Effects of antibiotics on cellular viability in porcine heart valve tissue. Cardiovasc Res 1990;23:960-4. 